\title{
PENERAPAN HUKUM PROGRESIF DALAM PERKARA PIDANA DI BIDANG NARKOTIKA
}

\author{
Indrawati \\ Fakultas Hukum Universitas Merdeka Malang \\ Jl. Terusan Dieng No. 62-64; Malang; 65146; Indonesia; (0341) 580161 \\ fir_fama@yahoo.co.id
}

\begin{abstract}
Narcotics abuse has become a necessity in the modern world. Law No. 35 of 2009 on Narcotics is strictly regulated on what actions can be categorized as criminal offenses and what sanctions will be faced by those legally and convincingly proven to be the perpetrators of narcotics abuse. In the past 5 years, the government has massively enforced law enforcement and law enforcement in the field of narcotics and has sent dozens of people to challenge death against firing squads in the execution process. Fidelis a civil servant from Sanggau West Kalimantan, was arrested by the BNN apparatus for being proven to plant marijuana at his home. Through a process integrated in the Indonesian criminal justice system, the judge finally ruled that Fidelis was legally and convincingly guilty and sentenced to 8 months in jail plus a fine of 1 billion 1-month subsidence cage. Many parties admit it because Fidelis should be tried and punished, but many also praise the courage of the judge who has decided the case by using the attachment of progressive legal theory.
\end{abstract}

Keywords: Narcotics, Abuse, and Progressive Law

\begin{abstract}
Abstrak
Penyalahgunaan narkotika sudah menjadi sebuah keniscayaan dalam dunia modern. Undang-undang Nomor 35 tahun 2009 tentang Narkotika, diatur secara tegas mengenai perbuatan apa yang dapat dikategorikan sebagai tindak pidana dan sanksi apa yang akan dihadapi oleh mereka yang secara sah dan meyakinkan terbukti sebagai pelaku penyalahgunaan narkotika. Dalam 5 tahun terakhir, pemerintah secara masifmelakukan penindakan dan penegakan hukum di bidang narkotika dan telah mengirimkan puluhan orang untuk menantang maut dihadap regu tembak dalam proses eksekusi mati. Fidelis seorang pegawai negeri dari sanggau Kalimantan barat, ditangkap oleh aparat BNN karena terbukti menanam ganja dirumahnya. Melalui suatu proses yang terangkai dalam sistem peradilan pidana Indonesia, hakim akhirnya memutuskan bahwa Fidelis secara sah dan meyakinkan bersalah dan dijatuhi hukuman 8 bulan penjara ditambah denda sebesar 1 Milyar subsider kurungan 1 bulan. Banyak pihak meyayangkan karena Fidelis harus diadili dan dihukum, tetapi banyak juga yang memuji keberanian hakim yang telah memutus perkara tersebut dengan menggunakan pengekatan teori hukum progresif.
\end{abstract}

Kata Kunci: Narkotika, Penyalahgunaan, dan Hukum Progresif 


\section{Pendahuluan}

Perkembangan masyarakat senantiasa lebih cepat dari perkembangan hukum, hal itu menyebabkan dalam praktik selalu lahir ketegangan antara hukum di satu sisi dan masyarakat di sisi yang lain. Belum lagi ketegangan antara tujuan hukum yakni bagaimana mewujudkan keadilan dalam masyarakat, memberikan kepastian hukum atau memberikan manfaat bagi masyarakat luas. Kasus yang dialami oleh Fidelis, masyarakat terbelah dalam dua kelompok yaitu yang membela dan yang menentang. Kasus Fandelis berkaitan dengan narkoba dimana, Kejahatan narkoba merupakan fenomena sosial yang terjadi pada setiap tempat dan waktu. Bahkan, disebut sebagai "a universal phenomenon", artinya merupakan fenomena yang berskala universal, dengan model, tipe, modus yang beraneka ragam (Suratman, 2016).

Membela menganggap bahwa Fidelis tidak seharusnya dihukum karena apa yang dilakukannya tidak didasari keinginan jahat untuk mencelakai atau merugikan orang lain, tetapi sebaliknya dimaksudkan untuk upaya pengobatan sang isteri yang pada kenyataannya mengalami penyakit yang tidak tersembuhkan. Sedangkan pihak yang menentang berpendapat bahwa atas alasan apapun Fidelis bukan pihak yang secara sah atau legal menggunakan Narkotika untuk tujuan pengobatan, dan penggunaan Narkotika secara demikian adalah tergolong penyalahgunaan sehingga sudah semestinya di hukum. Melihat fenomena ini, dapat dipahami bahwa masyarakat semakin memahami bahwa hukum sebagai sarana ketertiban, harus juga terus menyesuaikan diri dengan perkembangan masyarakat agar mampu menjawab persoalanpersoalan yang aktual.

Berdasarkan pemaparan diatas, maka dapat dirumuskan suatu permasalahan yang perlu dipecahkan berkaitan dengan hakim menerapkan hukum progresif dalam mengambil keputusan atas suatu perkara yang menjadi perhatian publik.

\section{A. Tinjauan Tentang Tindak Pidana}

Tindak pidana merupakan pengertian dasar dalam hukum pidana. Tindak pidana merupakan suatu pengertian yuridis, lain halnya dengan istilah perbuatan jahat atau kejahatan. Secara yuridis formal, tindak kejahatan merupakan bentuk tingkah laku yang melanggar undang-undang pidana. Oleh sebab itu setiap perbuatan yang dilarang oleh undang-undang harus dihindari dan arang siapa melanggarnya maka akan dikenakan pidana. Jadi larangan-larangan dan kewajiban-kewajiban tertentu yang harus ditaati oleh setiap warga Negara wajib dicantumkan dalam undang undang maupun peraturan-peraturan pemerintah, baik di tingkat pusat maupun daerah (Lamintang, 1996).

Tindak pidana adalah kelakuan manusia yang dirumuskan dalam undang-undang, melawan hukum, yang patut dipidana dan dilakukan dengan kesalahan. Orang yang melakukan perbuatan pidana akan mempertanggungjawabkan perbuatan dengan pidana apabila ia mempunyai kesalahan, seseorang mempunyai kesalahan apabila pada waktu melakukan perbuatan dilihat dari segi masyarakat menunjukan pandangan normatif mengenai kesalahan yang dilakukan (Hamzah, 2001).

Jenis-jenis tindak pidana dibedakan atas dasar-dasar tertentu, sebagai berikut:

a) Menurut Kitab Undang-Undang Hukum Pidana (KUHP) dibedakan antara lain kejahatan yang dimuat dalam Buku II dan Pelanggaran yang dimuat dalam Buku III. Pembagian tindak pidana menjadi "kejahatan" dan "pelanggaran" itu bukan hanya merupakan dasar bagi pembagian KUHP kita menjadi Buku ke II dan Buku ke III melainkan juga merupakan dasar bagi seluruh sistem hukum pidana di dalam perundang-undangan secara keseluruhan.

b) Menurut cara merumuskannya, dibedakan dalam tindak pidana formil (formeel Delicten) dan tindak pidana materil (Materiil Delicten). Tindak pidana formil adalah tindak pidana yang dirumuskan bahwa larangan yang di- 
rumuskan itu adalah melakukan perbuatan tertentu. Misalnya Pasal 362 KUHP yaitu tentang pencurian. Tindak Pidana materil inti larangannya adalah pada menimbulkan akibat yang dilarang, karena itu siapa yang menimbulkan akibat yang dilarang itulah yang dipertanggungjawabkan dan dipidana.

c) Menurut bentuk kesalahan, tindak pidana dibedakan menjadi tindak pidana sengaja (dolus delicten) dan tindak pidana tidak sengaja (culpose delicten). Contoh tindak pidana kesengajaan (dolus) yang diatur di dalam KUHP antara lain sebagai berikut: Pasal 338 KUHP (pembunuhan) yaitu dengan sengaja menyebabkan hilangnya nyawa orang lain, Pasal 354 KUHP yang dengan sengaja melukai orang lain. Pada delik kelalaian (culpa) orang juga dapat dipidana jika ada kesalahan, misalnya Pasal 359 KUHP yang menyebabkan matinya seseorang, contoh lainnya seperti yang diatur dalam Pasal 188 dan Pasal 360 KUHP.

d) Menurut macam perbuatannya, tindak pidana aktif (positif), perbuatan aktif juga disebut perbuatan materil adalah perbuatan untuk mewujudkannya diisyaratkan dengan adanya gerakan tubuh orang yang berbuat, misalnya Pencurian (Pasal 362 KUHP) dan Penipuan (Pasal 378 KUHP).

e) Tindak Pidana pasif dibedakan menjadi tindak pidana murni dan tidak murni. Tindak pidana murni, yaitu tindak pidana yang dirumuskan secara formil atau tindak pidana yang pada dasarnya unsur perbuatannya berupa perbuatan pasif, misalnya diatur dalam Pasal 224,304 dan 552 KUHP.Tindak Pidana tidak murni adalah tindak pidana yang pada dasarnya berupa tindak pidana positif, tetapi dapat dilakukan secara tidak aktif atau tindak pidana yang mengandung unsur terlarang tetapi dilakukandengan tidak berbuat, misalnya diatur dalam Pasal 338 KUHP, ibu tidak menyusui bayinya sehingga anak tersebut meninggal (Hamzah, 2001).
Berdasarkan uraian di atas, dapat diketahui bahwa jenis-jenis tindak pidana terdiri dari tindak pidana kejahatan dan tindak pidana pelanggaran, tindak pidana formil dan tindak pidana materil, tindak pidana sengaja dan tindak pidana tidak sengaja serta tindak pidana aktif dan pasif.

\section{B. Tinjauan tentang Narkotika}

Masyarakat luas mengenal istilah Narkotika yang kini telah menjadi fenomena berbahaya yang populer di tengah masyarakat kita. Ada pula istilah lain yang kadang digunakan adalah Narkoba (Narkotika dan Obat-obatan berbahaya). Selain itu ada pula istilah yang digunakan oleh DepKes RI yaitu NAPZA merupakan singkatan dari Narkotika, Pasikotropika dan Zat adiktif lainnya. Semua istilah diatas mengacu pada sekelompok zat yang mempunyai resiko kecanduan atau adiksi.

Penyalahgunaan narkotika merupakan tindak pidana kejahatan yang diancam dengan pidana. Penyalah guna narkotika bisa berkedudukan sebagai pelaku tindak pidana dan juga bisa berkedudukan sebagai korban tindak pidana. Penyalahguna Narkotika berkedudukan sebagai pelaku tindak pidana jika dengan sengaja tanpa hak atau melawan hukum menggunakan narkotika untuk diri sendiri, dan Penyalahguna Narkotika berkedudukan sebagai korban tindak pidana penyalahgunaan narkotika jika tidak sengaja tanpa hak atau melawan hukum (karena dibujuk, diperdaya, ditipu, dipaksa, dan/atau diancam) menggunakan narkotika (Setiyono, 2016).

Definisi Narkotika Secara umum yang dimaksud dengan narkotika adalah suatu kelompok zat yang bila dimasukkan dalam tubuh maka akan membawa pengaruh terhadap tubuh pemakai yang bersifat: 1) Menenangkan 2) Merangsang 3) Menimbulkan khayalan. Berdasarkan UndangUndang Republik Indonesia Nomor 35 Tahun 2009 Tentang Narkotika dapat dilihat pengertian dari Narkotika itu sendiri yakni: Pasal 1 ayat 1 . Narkotika adalah zat atau obat yang berasal dari tanaman 
atau bukan tanaman, baik sintetis maupun semisintetis, yang dapat menyebabkan penurunan atau perubahan kesadaran, hilangnya rasa, mengurangi sampai menghilangkan rasa nyeri, dan dapat menimbulkan ketergantungan, yang dibedakan ke dalam golongan golongan sebagaimana terlampir dalam Undang-Undang ini.

Jenis-Jenis Narkotika Adapun penggolongan jenis-jenis dari Narkotika berdasarkan Pasal 6 ayat (1) Undang-Undang Republik Indonesia Nomor 35 Tahun 2009 Tentang Narkotika, adalah sebagai berikut:

a) Narkotika golongan I: Narkotika yang hanya dapat digunakan untuk tujuan pengembangan ilmu pengetahuan dan tidak digunakan dalam terapi, serta mempunyai potensi sangat tinggi mengakibatkan ketergantungan. Antara lain sebagai berikut:

1) Tanaman Papaver Somniferum $L$ dan semua bagian bagiannya termasuk buah dan jeraminya, kecuali bijinya.

2) Opium mentah, yaitu getah yang membeku sendiri, diperoleh dari buah tanaman Papaver Somniferum L yang hanya mengalami pengolahan sekedar untuk pembungkus dan pengangkutan tanpa memperhatikan kadar morfinnya.

3) Opium masak terdiri dari: (a) candu, hasil yang diperoleh dari opium mentah melalui suatu rentetan pengolahan khususnya dengan pelarutan, pemanasan dan peragian dengan atau tanpa penambahan bahan-bahan lain, dengan maksud mengubahnya menjadi suatu ekstrak yang cocok untuk pemadatan. (b) jicing, sisasisa dari candu setelah dihisap, tanpa memperhatikan apakah candu itu dicampur dengan daun atau bahan lain. (c) jicing, hasil yang diperoleh dari pengolahan jicing.

4) Tanaman koka, tanaman dari semua genus Erythroxylon dari keluarga Erythroxylaceae termasuk buah dan bijinya.
5) Daun koka, daun yang belum atau sudah dikeringkan atau dalam bentuk serbuk dari semua tanaman genus Erythroxylon dari keluarga Erythroxylaceae yang menghasilkan kokain secara langsung atau melalui perubahan kimia.

6) Kokain mentah, semua hasil-hasil yang diperoleh dari daun koka yang dapat diolah secara langsung untuk mendapatkan kokain.

7) Kokaina, metil ester-1-bensoil ekgonina.

8) Tanaman ganja, semua tanaman genus genus cannabis dan semua bagian dari tanaman termasuk biji, buah, jerami, hasil olahan tanaman ganja atau bagian tanaman ganja termasuk damar ganja dan hasis.

b) Narkotika golongan II: Narkotika yang berkhasiat pengobatan, digunakan sebagai pilihan terakhir dan dapat digunakan dalam terapi dan/atau untuk tujuan pengembangan ilmu pengetahuan serta mempunyai potensi tinggi mengakibatkan ketergantungan.

c) Narkotika golongan III: Narkotika yang berkhasiat pengobatan dan banyak digunakan dalam terapi dan/atau untuk tujuan pengembangan ilmu pengetahuan serta mempunyai potensi ringan mengakibatkan ketergantungan.

Tindak Pidana Narkotika diatur dalam Bab XV Pasal 111 sampai dengan Pasal 148 Undangundang Nomor 35 tahun 2009 yang merupakan ketentuan khusus, walaupun tidak disebutkan dengan tegas dalam Undang-undang Narkotika bahwa tindak pidana yang diatur di dalamnya adalah tindak kejahatan, akan tetapi tidak perlu disangksikan lagi bahwa semua tindak pidana di dalam undang-undang tersebut merupakan kejahatan. Alasannya, kalau narkotika hanya untuk pengobatan dan kepentingan ilmu pengetahuan, maka apabila ada perbuatan diluar kepentingan kepentingan tersebut sudah merupakan kejahatan 
mengingat besarnya akibat yang ditimbulkan dari pemakaian narkotika secara tidak sah sangat membahayakan bagi jiwa manusia (Supramono, 2001). Pelaku Tindak Pidana Narkotika dapat dikenakan Undang-Undang No. 35 tahun 2009 tentang Narkotika, hal ini dapat diklasifikasikan sebagai berikut:

a. Sebagai pengguna dikenakan ketentuan pidana berdasarkan pasal 116 Undang-undang Nomor 35 tahun 2009 tentang Narkotika, dengan ancaman hukuman minimal 5 tahun dan paling lama 15 tahun.

b. Sebagai pengedar dikenakan ketentuan pidana berdasarkan pasal 81 dan 82 Undang-undang No. 35 tahun 2009 tentang narkotika, dengan ancaman hukuman paling lama $15+$ denda.

c. Sebagai produsen dikenakan ketentuan pidana berdasarkan pasal 113 Undang-undang No. 35 tahun 2009, dengan ancaman hukuman paling lama 15 tahun/ seumur hidup/ mati + denda.

\section{B. Tinjauan tentang Dasar Pertimbangan Hakim dalam Menjatuhkan Pidana}

Seorang hakim dalam hal menjatuhkan pidana kepada terdakwa tidak boleh menjatuhkan pidana tersebut kecuali apabila dengan sekurangkurangnya dua alat bukti yang sah, sehingga hakim memperoleh keyakinan bahwa suatu tindak pidana benar-benar terjadi dan terdakwalah yang bersalah melakukannya (Pasal 183 KUHAP). Alat bukti sah yang dimaksud adalah:
a. Keterangan Saksi;
b. Keterangan Ahli;
c. Surat;
d. Petunjuk;
e. Keterangan Terdakwa.

Hal - hal yang secara umum sudah diketahui sehingga tidak perlu dibuktikan (Pasal 184) (Rahardjo, 1998). Pasal 185 Ayat (2) KUHAP menyebutkan bahwa keterangan seorang saksi saja tidak cukup untuk membuktikan bahwa terdakwa bersalah terhadap perbuatan yang didakwakan kepadanya, sedangkan Pasal 185 dalam Ayat (3) dikatakan ketentuan tersebut tidak berlaku apabila disertai dengan suatu alat bukti yang sah lainnya (unus testis nullus testis). Saksi korban juga berkualitas sebagai saksi, sehingga apabila terdapat alat bukti yang lain sebagaimana dimaksud dalam ayat tersebut, maka hal itu cukup untuk menuntut pelaku tindak pidana (Rahardjo, 1998). Secara kontekstual ada tiga esensi yang terkandung dalam kebebasan hakim dalam melaksanakan kekuasaan kehakiman yaitu: (Rifai, 2010)

a. Hakim hanya tunduk pada hukum dan keadilan.

b. Tidak seorangpun termasuk pemerintah dapat mempengaruhi atau mengarahkan putusan yang akan dijatuhkan oleh hakim.

c. Tidak ada konsekuensi terhadap pribadi hakim dalam menjalankan tugas dan fungsi yudisialnya. Adapun beberapa teori atau pendekatan yang dapat dipergunakan oleh hakim dalam penjatuhan putusan dalam suatu perkara, yaitu sebagai berikut: (Rifai, 2010)

1) Teori keseimbangan Yang dimaksud dengan keseimbangan disini keseimbangan antara syarat syarat yang ditentukan oleh undang-undang dan kepentingan pihakpihak yang tersangkut atau berkaitan dengan perkara, yaitu antara lain seperti adanya keseimbangan yang berkaitan dengan masyarakat dan kepentingan terdakwa.

2) Teori pendekatan seni dan intuisi Penjatuhan putusan oleh hakim merupakan diskresi atau kewenangan dari hakim. Sebagai diskresi, dalam penjatuhan putusan hakim menyesuaikan dengan keadaan dan pidana yang wajar bagi setiap pelaku tindak pidana, hakim akan melihat keadaan pihak terdakwa atau penuntut umum dalam perkara pidana. Pendekatan seni dipergunakan oleh hakim dalam penjatuhan putusan, lebih ditentukan oleh 
instink atau intuisi dari pada pengetahuan dari hakim.

3) Teori Pendekatan Keilmuan Pendekatan Keilmuan ini merupakan semacam peringatan bahwa dalam memutus suatu perkara, Hakim tidak boleh sebatas dasar intuisi dan instink semata, tetapi harus dilengkapi dengan ilmu pengetahuan hukum dan ilmu pengetahuan lainnya.

4) Teori Pendekatan Pengalaman Pengalaman seorang Hakim merupakan hal yang dapat membantunya dalam menghadapi perkara-perkara yang dihadapinya seharihari, karena dengan pengalaman yang dimilikinya seorang hakim mengetahui bagaimana dampak dari putusan yang dijatuhkan dalam suatu perkara pidana.

5) Teori Ratio Decidendi Teori ini didasarkan pada landasan filsafat yang mendasar, yang mempertimbangkan segala aspek yang berkaitan dengan pokok perkara yang dipermasalahkan.

6) Teori Kebijaksanaan Teori ini diperkenalkan oleh Made Sadhi Astuti, dimana sebenarnya teori ini berkenaan dengan putusan hakim dalam perkara di pengadilan anak. Aspek ini menekankan bahwa pemerintah, masyarakat, keluarga dan orang tua ikut bertanggungjawab untuk membimbing, membina, mendidik dan melindungi anak agar kelak dapat menjadi manusia yang berguna bagi keluarganya, masyarakat dan bangsanya. Teori lain yang berkaitan dengan dasar pertimbangan hakim, yaitu dalam mengadili pelaku tindak pidana, maka proses menyajikan kebenaran dan keadilan dalam suatu putusan pengadilan sebagai rangkaian proses penegakan hukum, maka dapat dipergunakan teori kebenaran. Dengan demikian, putusan pengadilan dituntut untuk memenuhi teori-teori sebagai berikut: a. Teori koherensi atau kosistensi Teori yang membuktikan adanya saling berhubungan antara bukti yang satu dengan bukti yang lain, misalnya, antara keterangan saksi yang satu dengan keterangan saksi yang lain. Atau, saling berhubungan antara keterangan saksi dengan alat bukti yang lain (alatalat bukti yang tertuang dalam Pasal 184 KUHAP). Dalam hal seperti ini dikenal adanya hubungan kausalitas yang bersifat rasional a priori.

b. Teori korespodensi Jika ada faktafakta di persidangan yang saling bersesuaian, misalnya, antara keterangan saksi bersesuaian dengan norma atau ide. Jika keterangan saksi Mr. X menyatakan bahwa pembangunan proyek yang dilakukan oleh Mr. Y tidak melalui proses lelang tetapi dilaksanakan melalui penunjukan langsung Perusahaan Z. Persesuaian antara fakta dengan norma ini terlihat dalam hubungan kuasalitas yang bersifat empiris a pesteriori.

c. Teori utilitas Teori ini dikenal pula dengan pragmatik, kegunaan yang bergantung pada manfaat (utility), yang memungkinkan dapat dikerjakan (workbility), memiliki hasil yang memuaskan (satisfactory result) (Mulyadi, 2007).

Masalah kebebasan hakim merupakan suatu masalah yang cukup dilematis dalam usaha penegakan hukum dan keadilan. Seperti yang terdapat didalam Undang Undang Dasar Republik Indonesia tahun 1945 mengenai masalah kebebasan hakim atau kebebasan peradilan merupakan syarat mutlak bagi adanya negara hukum. Karena tanpa adanya jaminan kebebasan peradilan didalam negara tersebut, maka masih diragukan adanya supermasi hukum diatas segala-galanya. Apa yang 
dikatakan oleh A.V. Dicey tentang Rule of Law yang meliputi tiga unsur yaitu:

a. Supremasi hukum artinya bahwa yang mempunyai kekuasaan yang tertinggi didalam negara adalah hukum.

b. Persamaan dalam kedudukan hukum bagi setiap orang.

c. Konstitusi itu tidak merupakan dari hak-hak asasi manusia dan jika hak hak asasi manusia itu diletakkan dalam konstitusi itu hanya sebagai penegasan bahwa hak asasi itu harus dilindungi (Kusnardi \& Ibrahim, 1986).

Kebebasan hakim bukanlah dimaksudkan dengan semacam hak istimewa dari para hakim untuk dapat berbuat sebebas-bebasnya seperti halnya dengan kebebasan kampus dan kebebasan pers. Bahwa kebebasan hakim yang dimaksud mengandung tiga arti yaitu:

a. Sifat kebebasan hakim/pengadilan;

b. Seberapa jauh kebebasan hakim dalam menangani suatu perkara;

c. Gunanya hakim/pengadilan diberi kebebasan (Dewantara, 1987).

Tugas seorang hakim dalam menyelenggarakan peradilan adalah menegakkan hukum sehingga hakim dalam memutuskan suatu perkara harus berdasarkan hukum, artinya tidak boleh bertentangan dengan hukum. Karena hakim mempertahankan tertib hukum, menetapkan apa yang ditentukan oleh hukum dalam suatu perkara yang diajukan kepadanya. Bagi seorang terdakwa diharapkan dari hakim adalah hakim tersebut akan menerapkan hukum terhadapnya sesuai dengan hukum yang berlaku dan sesuai dengan kesadaran hukum serta rasa keadilan didalam masyarakat. Jadi sifat kebebasan hakim tersebut merupakan suatu kebebasan yang diberi batas-batas oleh Undang-undang yang berlaku. Sebab hakim diberi kebebasan, hanya seluas dan sejauh yang berhubungan dengan keputusannya tersebut untuk mencapai suatu keadilan dalam menyelesaikan suatu perkara. Pada akhirnya, tujuan hakim diberi kebebasan itu ialah untuk mencapai negara hukum Republik Indonesia. Dapat disimpulkan bahwa kebebasan yang dimaksud adalah kebebasan yang terikat/terbatas.

\section{Penerapan Hukum Progresif Dalam Hukum Pidana}

Hukum dan keadilan merupakan dua buah sisi mata uang yang tidak dapat dipisahkan, hukum bertujuan untuk mewujudkan keadilan dan keadilan tanpa hukum ibarat macan ompong. Namun untuk mendapatkan keadilan maka pencari keadilan harus melalui prosedur-prosedur yang tidak adil. Sehingga hukum menjadi momok yang menakutkan bagi masyarakat, hukum bukan lagi untuk membahagiakan masyarakat tetapi malah menyengsarakan masyarakat. Hukum gagal memberikan keadilan ditengah masyarakat. Supremasi hukum yang selama ini didengungkan hanyalah sebagai tanda (sign) tanpa makna. Teks-teks hukum hanya permainan bahasa (language of game) yang cenderung menipu dan mengecewakan.

Salah satu penyebab yang terjadi didalam dunia hukum adalah karena masih terjerembab kepada paradigma tunggal positivisme yang sudah tidak fungsional lagi sebagai analisis dan kontrol yang bersejalan dengan tabel hidup karakteristik manusia yang senyatanya pada konteks dinamis dan multi kepentingan baik pada proses maupun pada peristiwa hukumnya (Usman, 2009). Sehingga hukum hanya dipahami dalam artian yang sangat sempit, yakni hanya dimaknai sebatas undangundang, sedangkan nilai-nilai diluar undangundang tidak dimaknai sebagai sebuah hukum.

Hukum Progresif memecahkan kebuntuan itu. Hukum progresif menuntut keberanian aparat hukum menafsirkan pasal untuk memperadabkan bangsa. Apabila proses tersebut benar, idealitas yang dibangun dalam penegakan hukum di Indonesia sejajar dengan upaya bangsa mencapai tujuan 
bersama. Idealitas itu akan menjauhkan dari praktek ketimpangan hukum yang tak terkendali seperti sekarang ini. Sehingga Indonesia dimasa depan tidak ada lagi dskriminasi hukum, bagi kaum papa karena hukum tak hanya melayani kaum kaya. Apabila kesetaraan didepan hukum tak bisa diwujudkan, keberpihakan itu mutlak. Manusia menciptakan hukum bukan hanya untuk kepastian, tetapi juga untuk kebahagiaan.

Menurut Satjipto Rahardjo, Penegakan hukum progresif adalah menjalankan hukum tidak hanya sekedar kata-kata hitam-putih dari peraturan (according to the letter), melainkan menurut semangat dan makna lebih dalam (to very meaning) dari undangundang atau hukum. Penegakan hukum tidak hanya kecerdasan intelektual, melainkan dengan kecerdasan spiritual. Dengan kata lain, penegakan hukum yang dilakukan dengan penuh determinasi, empati, dedikasi, komitmen terhadap penderitaan bangsa dan disertai keberanian untuk mencari jalan lain daripada yang biasa dilakukan (Rahardjo 2009).

Sistem hukum dimanapun didunia, keadilan selalu menjadi objek perburuan, khususnya melalui lembaga pengadilannya. Keadilan adalah hal yang mendasar bagi bekerjanya suatu sistem hukum. Sistem hukum tersebut sesungguhnya merupakan suatu struktur atau kelengkapan untuk mencapai konsep keadilan yang telah disepakati bersama (Rahadjo, 2006). Merumuskan konsep keadilan progresif ialah bagaimana bisa menciptakan keadilan yang subtantif dan bukan keadilan prosedur. Akibat dari hukum modren yang memberikan perhatian besar terhadap aspek prosedur, maka hukum di Indonesia dihadapkan pada dua pilihan besar antara pengadilan yang menekankan pada prosedur atau pada substansi. Keadilan progresif bukanlah keadilan yang menekan pada prosedur melainkan keadilan substantif.

Kerusakan dan kemerosotan dalam perburuan keadilan melalui hukum modren disebabkan permainan prosedur yang menyebabkan timbulnya pertanyaan "apakah pengadilan itu mencari keadil- an atau kemenangan?". Proses pengadilan dinegara yang sangat sarat dengan prosedur (heavly proceduralizied) menjalankan prosedur dengan baik ditempatkan diatas segala-galanya, bahkan diatas penanganan substansi (accuracy of substance). Sistem seperti itu memancing sindiran terjadinya trials without truth (Rahardjo, 2006).

Dalam rangka menjadikan keadilan subtantif sebagai inti pengadilan yang dijalankan di Indonesia, Mahkamah Agung memegang peranan yang sangat penting. Sebagai puncak dari badan pengadilan, ia memiliki kekuasaan untuk mendorong (encourage) pengadilan dan hakim dinegeri ini untuk mewujudkan keadilan yang progresif tersebut. Hakim menjadi faktor penting dalam menentukan, bahwa pengadilan di Indonesia bukanlah suatu permainan (game) untuk mencari menang, melainkan mencari kebenaran dan keadilan. Keadilan progrsif semakin jauh dari cita-cita "pengadilan yang cepat, sederhana, dan biaya ringan" apabila membiarkan pengadilan didominasi oleh "permainan" prosedur. Proses pengadilan yang disebut fair trial dinegeri ini hendaknya berani ditafsirkan sebagai pengadilan dimana hakim memegang kendali aktif untuk mencari kebenaran (Rahardjo, 2006).

\section{Tinjauan tentang Putusan Majelis Hakim Pengadilan Negeri Sanggau Kepada Fidelis Ari Sudewarto}

Majelis yang dipimpin Achmad Irfir Rohman dengan hakim anggota John Sea Desa dan Maulana Abdulah menilai Fidelis terbukti bersalah. Fidelis telah memiliki 39 batang ganja, meski dengan alasan pengobatan bagi istrinya. Perbuatan Fidelis dinilai memenuhi unsur Pasal 111 dan 116 UndangUndang Republik Indonesia Nomor 35 tentang Narkotika. Jaksa menuntut Fidelis hukuman lima bulan penjara dan denda Rp 800 juta subsider satu bulan kurungan. Dengan demikian, hakim memutus lebih berat daripada tuntutan jaksa.

Meski dihukum, vonis untuk Fidelis jauh lebih ringan dibandingkan dengan terdakwa 
dalam kasus narkoba yang lain. Menurut hakim, salah satu yang meringankan vonis adalah bahwa Fidelis terbukti menanam ganja tidak atas dasar niat jahat dan mencelakakan orang lain, terutama istrinya. Tindak pidana penyalahgunaan narkotika merupakan tindak pidana yang unik, seperti halnya tindak pidana perjudian. Keunikan dari tindak pidana ini terletak pada status kedudukan Penyalahguna Narkotika itu sendiri. Status Penyalahguna Narkotika itu apakah sebagai pelaku tindak pidana atau sebagai korban tindak pidana. Kebanyakan orang menganggap bahwa penyalahguna narkotika adalah pelaku sekaligus korban tindak pidana, namun sebenarnya apakah memang demikian? Status kedudukan yang demikian ini penting diketahui, dipahami karena akan lebih mudah menentukan kebijakan legislasi yang tepat apakah penyalahguna narkotika itu dapat dipertanggungjawabkan dalam hukum pidana atau tidak, atau sanksi apa yang tepat bagi mereka (Setiyono, 2016).

Dalam memutuskan, majelis hakim memperhatikan tiga hal, yaitu yuridis, sosiologis dan filosofis. Ketiganya memiliki porsi yang seimbang," kata Hakim Irfir di muka persidangan. Pakar hukum pidana Dr. Syarif Hasyim Azizurahman, S.H., M.Hum mengatakan, hakim tentunya tidak hanya melihat prinsip kepastian hukum tetapi juga keadilan hukum. Dalam posisi di mana ada pertentangan antara kepastian hukum dan keadilan hukum, maka yang harus didahulukan adalah prinsip keadilan hukum. Dekan Fakultas Hukum Universitas Tanjungpura, Pontianak, Kalimantan Barat ini melihat, prinsip keadilan hukum sudah diterapkan dalam kasus ini. Sesuai undang-undang, ancaman hukuman minimal untuk tindakan yang dilakukan Fidelis adalah pidana 4 tahun penjara.

Karena jaksa hanya menuntut 5 bulan dan hakim memutus 8 bulan, kata Azizurahman, maka pengadilan sebenarnya sudah mengarah ke keadilan hukum. Sangat sulit untuk berharap hukuman bebas murni, karena ada unsur yang terbukti.

Kasus ini, hakim dan jaksa sudah mempertimbangkan posisi kasus ini yang tujuannya bukan untuk menguntungkan diri sendiri atau orang lain, tetapi dalam kapasitas penyembuhan. Karena itu, vonis 8 bulan itu akhirnya dijatuhkan, tanpa melihat bahwa sesuai aturan hukuman minimalnya 4 tahun. Azizurahman mengapresiasi hakim yang nampaknya tidak kaku mengikuti undang-undang yang berlaku. Apresiasi yang sama juga diberikan kepada penegak hukum yang lain termasuk jaksa, yang mempertimbangkan alasan dan tujuan Fidelis menanam ganja, yaitu sebagai bagian dari upaya penyembuhan istrinya. Kalau dilihat dari sudut pandang hakim atau jaksa penuntut umum, ini adalah keputusan yang progresif.

\section{Kesimpulan}

Berdasarkan pemaparan diatas, maka dapat disimpulkan bahwa untuk mengurangi ketegangan antara tujuan hukum berupa keadilan dan kepastian hukum, maka diperlukan suatu pembaharuan melalui pendekatan hukum progresif dimana hakim menjadi tokoh sentral dalam usaha untuk membuat hukum menjadi lebih responsive. Sekalipun dalam suatu perkara seseorang terbukti secara sah melakukan tindak pidana, seperti halnya Fidelis yang terbukti menanam ganja, tetapi oleh karena terbukti bahwa yang bersangkutan bukan seorang pemakai, pengedar, atau bandar, maka dengan pertimbangan kemanusiaan maka jaksa dan hakim mencoba menghadirkan keadilan substantif melalui pendekatan hukum progresif dengan menjatuhkan hukuman lebih rendah dari ancaman yang seharusnya. Dengan demikian hakim memberikan kepastian hukum di satu sisi dan menghadirkan keadilan disisi lainnya.

\section{DAFTAR PUSTAKA}

Dewantara, Nanda Agung. 1987. Masalah Kebebasan Hakim Dalam Menangani Suatu Perkara Pidana. Aksara Persada Indonesia. Jakarta.

Hamzah, Andi. 2001. Bunga Rampai Hukum Pidana dan Acara Pidana. Ghalia Indonesia Jakarta. 


\section{Jurnal Cakrawala Hukum}

Vol.8, No.2 Desember 2017: 171-180

Kusnardi, M. dan Ibrahim, Harmaily. 1986. Pengantar Hukum Tata Negara Indonesia. FH-UI. Jakarta.

Lamintang, P.A.F. 1996. Dasar-Dasar Hukum Pidana Indonesia. Citra Adityta Bakti. Bandung.

Mulyadi, Lilik. 2007. Kekuasaan Kehakiman. Bina Ilmu, Surabaya.

Rahardjo, Satjipto. 1998. Bunga Rampai Permasalahan Dalam Sistem Peradilan Pidana. Pusat Pelayanan Keadilan dan Pengabdian Hukum. Jakarta.

Rahardjo, Satjipto. 2006. Membedah Hukum Progresif. Buku Kompas. Jakarta.

Rahardjo, Satjipto. 2009. Penegakan Hukum Suatu Tinjauan Sosiologis. Genta Publishing. Yogyakarta.

Rifai, Ahmad. 2010. Penemuan Hukum oleh Hakim dalam Persfektif Hukum Progresif. Sinar Grafika. Jakarta.
Setiyono, S. 2016. Reorientasi Kebijakan Pemidanaan Bagi Penyalahguna Narkotika. Jurnal Cakrawala Hukum, 7(1), 56-65. doi:10.26905/idjch.v7i1.1782

Supramono, G. 2001. Hukum Narkotika Indonesia. Djambatan. Jakarta.

Suratman, T. 2016. Pembinaan Narapidana Narkotika dan Obat Obatan Berbahaya (Narkoba) Dalam Perspektif Kehidupan Religiusitas. Jurnal Cakrawala Hukum, 7(1), 66-81. doi:10.26905/ idjch.v7i1.1783

Usman, Sabian. 2009. Dasar-Dasar Sosiologi Hukum, Pustaka Belajar, Yogyakarta.

How to cite:

Indrawati. 2017. Penerapan Hukum Progresif Dalam Perkara Pidana Di Bidang Narkotika. Jurnal Cakrawalah Hukum, 8(2). 